\title{
Analisis Rendahnya Laporan Insiden Keselamatan Pasien di Rumah Sakit
}

\author{
An Analysis of Low Adverse Error Reporting at Hospital \\ Gunawan, Fajar Yuli Widodo, Tatong Harijanto \\ Program Studi Magister Manajemen Rumah Sakit Fakultas Kedokteran Universitas Brawijaya Malang
}

\begin{abstract}
ABSTRAK
Data laporan IKP yang akurat sangat bermanfaat untuk pemetaan risiko keselamatan pasien dan dasar perbaikan sistem pelayanan yang berorientasi pada keselamatan pasien. Penelitian ini bertujuan untuk menganalisa rendahnya laporan IKP dan faktor yang berpengaruh pada sistem pelaporan IKP di salah satu Rumah Sakit (RS) Malang. Metode yang digunakan adalah diskripsi analitik. Penggalian data dilakukan dengan telusur data laporan IKP, observasi lapangan, wawancara terstruktur dan survei dengan menggunakan kuesioner. Responden pada penelitian ini adalah 20 petugas kesehatan dan keluarga pasien sebanyak 6 orang. Analisis data dilakukan secara deskriptif untuk melihat distribusi frekuensi menggunakan microsoft excel. Hasil menunjukkan angka IKP lebih tinggi dari angka laporan IKP. Faktor penyebabnya adalah rendahnya laporan IKP yang disebabkan oleh rasa takut pada kepala unit kerja.Kesimpulan dari penelitian ini adalah data laporan IKP belum menggambarkan kondisi sebenarnya dari kejadian insiden keselamatan pasienyang terjadi di RS X. Faktor penyebab utama kondisi tersebut adalah kurangnya pemahaman tentang konsep pelaporan IKP.
\end{abstract}

Kata Kunci: Budaya keselamatan pasien, insiden keselamatan pasien

\section{ABSTRACT}

An accurate data of adverse error report is very useful for mapping the risk of patient safety and the basic of improvement on services system oriented on patient safety. This study aims to analyze low adverse error reports and factors affecting the adverse error report system in X Hospital Malang. The method used was analytic description. Data collection was carried out by data searching on adverse error reports, field observation, structured interviews, and surveys using questionnaires. Respondents in this study were 20 health care workers and patients' families as many as 6 people. Data analysis was done descriptively to see the distribution frequency using Microsoft excel. Results show the figures are higher than the data on adverse error reports. The contributing factor on the lack of adverse error reports is caused by fear on the head unit. The study concludes that the reported data of adverse error reports do not describe the actual condition of patient safety incidents that occurred in the $X$ hospital. The main factor of these conditions is the lack of understanding of the concept of reporting adverse errors.

Keywords: Adverse event reporting, hospital, patient safety culture

Jurnal Kedokteran Brawijaya, Vol. 28, Suplemen No. 2, 2015; Korespondensi: Gunawan. Program Studi Magister Manajemen Rumah Sakit Fakultas Kedokteran Universitas Brawijaya Malang, Jl. Veteran Malang 65145 Tel. (0341) 569117 Email: gunawan.yuwandi@gmail.com 


\section{PENDAHULUAN}

Keselamatan pasien (patient safety) adalah suatu sistem di rumah sakit yang membuat asuhan pasien lebih aman. Sistem tersebut meliputi penilaianrisiko, identifikasi dan pengelolaan hal yang berhubungan dengan risiko pasien, pelaporan dan analisis insiden, kemampuan belajar dari insiden dan tindak lanjutnya serta implementasi solusi untuk meminimalkan timbulnya risiko. Sistem tersebut diharapkan dapat mencegah terjadinya cedera yang disebabkan oleh kesalahan akibat melaksanakan suatu tindakan atau tidak melakukan tindakan yang seharusnya dilakukan (1). Salah satu tujuan dari keselamatan pasien adalah mengurangi angka insiden keselamatan pasien (IKP). Insiden keselamatan pasien adalah setiap kejadian yang tidak disengaja dan kondisi yang mengakibatkan cedera yang dapat dicegah pada pasien. IKP terdiri dari kejadian tidak diharapkan (KTD), kejadian nyaris cedera (KNC), kejadian tidak cedera (KTC), kejadian potensial cedera (KPC) dan sentinel (1).

Institute of Medicine (IOM) di Amerika Serikat menerbitkan laporan yang mengejutkan banyak pihak pada tahun 2000 yang berjudul: "To Err is Human ", Building a Safer Health System. Laporan tersebut mengemukakan tentang angka KTD di RS Utah dan Corolado sebesar 2,9\%, dengan 6,6\% diantaranya meninggal.Di New York ditemukan angka KTD sebesar $3,7 \%$ dengan angka kematian $13,6 \%$. Publikasi WHO pada tahun 2004, yang mengumpulkan data penelitian rumah sakit di berbagai negara: Amerika, Inggris, Denmark dan Australia melaporkan data KTD dengan rentang 3,2-16,6\% (1). Penelitian di Canada menunjukkan bahwa $7 \%-12 \%$ pasien mengalami insiden keselamatan yang 30\%-40\% nya sebenarnya dapat dilakukan pencegahan (2).

Laporan IKP di Indonesia tahun 2007 berdasarkan provinsi menemukan bahwa145 insiden yang dilaporkan, kasus tersebut terjadi di wilayah Jakarta sebesar 37,9\%, Jawa Tengah 15,9\%, DI Yogyakarta 13,8\%, Jawa Timur 11,7\%, Sumatra Selatan 6,9\%, Jawa Barat 2,8\%, Bali 1,4\%, Sulawesi Selatan 0,69\% dan Aceh 0,68\%. Laporan IKP di Indonesia berdasarkan kepemilikan rumah sakit tahun 2010 pada triwulan III ditemukan bahwa rumah sakit Pemerintah Daerah memiliki presentasi lebih tinggi sebesar $16 \%$ dibandingkan rumah sakit swasta sebesar $12 \%(3)$.

Pada data laporan IKP di RS X Malang didapatkan 55 insiden keselamatan pasien atau 1,03\% dari seluruh kunjungan pasien rawat inap tahun 2012 dan 30 insiden atau 0,44\% pada tahun 2013 (4,5). Angka ini adalah jauh lebih kecil dibandingkan dengan angka statistik internasional maupun nasional. Kondisi ini perlu mendapatkan perhatian dan pengkajian secara obyektif untuk memastikan apakah data tersebut benar atau tidak, karena data IKP sangat bermanfaat untuk melakukan evaluasi dan perbaikan sistem pelayanan yang berbasis keselamatan pasien. Pelaporan IKP adalah salah satu langkah dan syarat untuk membangun budaya keselamatan pasien (1). Pelaporan yang baik akan memberikan dukungan positif terhadap upaya-upaya identifikasi risikoinsiden yang menyebabkan ancaman keselamatan pasien (6). Pelaporan yang baik juga akan memberikan respon positif untuk membangun sistem pelayanan yang berorientasi pada keselamatan pasien dengan mendasarkan pada evident based (7).
Pelaporan IKP memerlukan keterlibatan dan komitmen yang tinggi dari organisasi dan individu pemberi pelayanan (8). Kingston dalam penelitiannya menemukan bahwa $76 \%-82 \%$ insiden keselamtan pasien tidak dilaporkan (9). Faktor penghalang pelaporan IKP diantaranya adalah: sikap hanya melaporkan kesalahan jika kesalahan tersebut mengakibatkan kerugian, tidak menyadari jika suatu kesalahan telah terjadi karena kurangnya kemampuan mengidentifikasi,tidak ada manfaat untuk melaporkan, kurangnya motivasi (10), ketakutan untuk melaporkan, karena konsekuensi yang harus diterima (11), tanggapan negatif dari manajer organisasi (12), persepsi bahwa tempat kerja mempunyai budaya keselamatan yang lemah, kurangnya pengetahuan dan ketrampilan yang terkait dengan insiden keselamatan pasien, kurangnya umpan balik terhadap pelaporan, kurangnya waktu untuk membuat pelaporan, hal ini terkait dengan beban kerja, takut disalahkan, lemahnya kepemimpinan organisasi terhadap keselamatan pasien (6).

Pada penelitian ini dilakukan analisis rendahnya laporan insiden keselamatan pasien di RSI X Malang dan mengidentifikasi faktor yang menjadi penyebabnya. Studi ini diharapkan dapat memberikan informasi dan data yang objektif tentang pelaksanaan sistem keselamatan pasien terutama dari aspek pelaporan IKP yang terjadi di RS $\mathrm{X}$ Malang.

\section{METODE}

Penelitian ini menggunakan metode observasi dan survei. Observasi bertujuan untuk mendapatkan gambaran langsung pelayanan pasien dan melakukan identifikasi kejadian IKP. Identifikasi kejadian IKP didasarkan pada panduan nasional keselamatan pasien rumah sakit, yang terdiri dari KTD, KNC, KTC, KPC dan sentinel. Survei dilakukan dengan menggunakan metode wawancara terstruktur dan kuesioner. Metode survei dilakukan untuk mendapatkan gambaran pelaksanaan program keselamatan pasien, sistem pelaporan IKP dan faktorfaktor yang berpengaruh pada pelaporan IKP oleh petugas di RS X Malang.

Observasi yang dilakukan di 3 area, yaitu IGD pada tanggal 9 Oktober 2014, ruang rawat inap Ali tanggal 10 Oktober 2014 dan pelayanan farmasi rawat jalan tanggal 13 Oktober 2014. Masing-masing area dilakukan observasi selama 1-2 jam. Kegiatan observasi meliputi pengamatan langsung pada pelayanan pasien, sarana prasarana dan pengelolaan obat-obatan untuk pertolongan gawat darurat.

Responden wawancara terstuktur adalah pejabat struktural, pejabat fungsional, pimpinan unit kerja dan tim sub komite keselamatan pasien rumah sakit (KPRS). Wawancara dengan pejabat RS dilakukan terhadap 1 orang pejabat struktural yaitu kepala bidang keperawatan dan 1 orang pejabat fungsional yaitu ketua mutu RS, dengan tujuan untuk mendapatkan data sistem manajemen keselamatan pasien RS dan faktor-faktor yang mendukung dan menghambat pelaksanaan program keselamatan. Wawancara dengan pimpinan unit kerja dilakukan terhadap 3 orang yaitu kepala IGD, Kepala instalasi farmasi dan kepala ruang rawat inap, dengan tujuan untuk mendapatkan data gambaran pelaksanaan sistem keselamatan dan kendala yang dihadapi dalam pencapaian program keselamatan. Wawancara dengan tim subkomite 
KPRS dilakukan terhadap 3 orang, yaitu ketua, sekretaris dan 1 orang anggota.Kegiatan ini dilakukan untuk menggali permasalahan atau kendala yang terjadi terkait penerapan program keselamatan pasien dari aspek sistem pelaporan IKP. Wawancara terstruktur juga dilakukan terhadap pasien dan keluarga untuk mendapatkan informasi tentang pemahaman pasien atau keluarga terhadap penerapan keselamatan pasien di RSIA.

Survei dengan kuesioner menggunakan responden petugas sebanyak 20 responden, yang terdiri dari perawat ruangan rawat inap, perawat IGD, petugas apotik dan petugas laboratorium. Kuesioner menggunakan skala pengukuran nominal.Focus group discusion (FGD) dilakukan bersama perwakilan tim sub komite KPRS sebanyak 6 orang. Kegiatan ini ditujukan untuk merumuskan akar permasalahan rendahnya IKP. Pengolahan datahasil kuesioner dilakukan tabulasi dengan menggunakan Microsoft Excel 2013 (Microsoft Corp USA). Hasil wawancara terstruktur dan FGD diolah dan ditampilkan dalam bentuk tabel.

\section{HASIL}

\section{Insidendan Potensi Insiden Keselamatan Pasien}

Kegiatan observasi dilakukan untuk mendapatkan gambaran langsung proses pelayanan di RS X Malang dan mengidentifikasi IKP. Identifikasi IKP dilakukan terhadap semua dimensi yaitu KTD, KNC, KTC, KPC dan sentinel. Hasil observasi menunjukkan bahwa hanya dalam waktu masa observasi yang pendek ditemukan 30 IKP yang terdiri dari kejadian tidak cedera (KTC) sebanyak 12 kasus dan kejadian potensial cedera (KPC) sebanyak 18 kasus. Gambaran temuan IKP yang diperoleh pada saat observasi lapangan terdapat pada Tabel 1.

\section{Tabel 1. Hasil observasi identifikasi IKP}

\begin{tabular}{|c|c|}
\hline \multicolumn{2}{|c|}{ Rincian IKP } \\
\hline \multicolumn{2}{|c|}{ Ruang rawat inap: } \\
\hline 1. & $\begin{array}{l}\text { Ditemukan persediaan obat emergency yang kosong, yaitu } \\
\text { ephinefrin dan imodexon injeksi }\end{array}$ \\
\hline 2. & $\begin{array}{l}\text { Penggunaan handscoon saat akan melakukan tindakan pada } \\
\text { pasien tidak selalu dilakukan }\end{array}$ \\
\hline 3. & $\begin{array}{l}\text { Jarum bekas tindakan infus pasien diletakkan menjadi satu } \\
\text { dengan torniquet }\end{array}$ \\
\hline 4. & $\begin{array}{l}\text { Kedisiplinan petugas untuk melakukan cuci tangan sesuai } \\
\text { dengan } 5 \text { momen cuci tangan masih kurang. }\end{array}$ \\
\hline 5. & $\begin{array}{l}\text { Tabung oksigen diletakkan disamping penderita tanpa } \\
\text { pengaman }\end{array}$ \\
\hline 6. & $\begin{array}{l}\text { Peletakan sampah medis berdampingan dengan peletakan } \\
\text { instrumen tindakan yang masih steril }\end{array}$ \\
\hline \multirow[t]{4}{*}{7.} & Observasi saat perawat melakukan injeksi pasien : \\
\hline & $>$ handscoon tidak digunakan \\
\hline & $>$ Tidak menerapkan 5 momencuci tangan \\
\hline & $\begin{array}{l}\text { Spuit bekas tindakan injeksi diletakkan menjadi satu } \\
\text { dengan spuit berisi obat yang belum diinjeksikan }\end{array}$ \\
\hline Apotik rawat jalan: & k rawat jalan: \\
\hline 1. & Belum diberlakukan nomer antrian resep \\
\hline 2. & $\begin{array}{l}\text { Penjelasan pemakaian obat belum sesuai dengan pedoman } \\
\text { penyediaan obat (belum ada penjelasan waktu minum obat } \\
\text { dan efek samping) }\end{array}$ \\
\hline 3. & $\begin{array}{l}\text { Petugas tidak selalu melakukan cuci tangan saat akan } \\
\text { meracikobat }\end{array}$ \\
\hline 4. & $\begin{array}{l}\text { Belum ada informasi kandungan obat yang terdapat pada } \\
\text { obat racikan }\end{array}$ \\
\hline
\end{tabular}

Tabel 1. Hasil observasi identifikasi IKP (Lanjutan)

\begin{tabular}{lc}
\hline Rincian IKP & $\begin{array}{c}\text { Jumlah } \\
\text { IKP }\end{array}$ \\
\hline IGD: & 19
\end{tabular}

IKP pada pelayanan Ny.X 60 tahun dengan tindakan aspirasi cairan sinovial genu dekstra :

1. Pengaman bed pasien tidak terpasang sempurna

2. Letak standar infus berseberangan dengan lokasi infus, selang infus menyilang badan pasien

3. Tidak ada konfirmasi identitas pasien saat dokter akan melakukan tindakan

4. Komunisasi dokter dan perawat saat akan melakukan tindakan kurang optimal

5. Informedconsent tidak dilakukan sebelum tindakan dilaksanakan

6. Pelaksanaan tindakan kurang memenuhi kaidah aseptik

7. Perawat tidak mendampingi dokter saat tindakan dilakukan

8. Perawat masih menggunakan handscoon yang dipakai saat menangani Ny.X ketika melayani px. Lain

9. Spesimen cairan sendi diletakkan menjadi satu dengan bengkok yang bercampur dengan spuit steril

10. Dokter meninggalkan lokasi tanpa terlebih dahulu mengisi berkas rekam medis pasien.

11. Permintaan uji laboratorium spesiman didelegasikan kepada dokter jaga dengan kurang memenuhi standar komunikasi efektif

Observasi secara umum pada proses pelayanan :

1. Pengaman tempat tidur pasien sering tidak terpasang sempurna

2. Petugas tidak selalu melakukan identifikasi pasien saat akan melakukan tindakan.

3. Intruksi tindakan disampaikan perawat kepada perawat lain secara verbal dan berurutan untuk beberapa pasien dan tindakan yang berbeda - beda. Sering petugas pelaksana tidak melakukan cek pada status Px.

4. Tidak ada cheklistuntuk mengidentifikasi tindakan yang sudah dilakukan yang terpasang pada tempat tidur pasien

5. Penjelasan inform concerndilakukan oleh perawat, yang seharusnya dilakukan oleh dokter.

6. Belum diberlakukan sistem triage di IGD

Pengamatan sarana prasarana :

1. Terdapat alat medis yang habis masa kalibrasinya : nebulizer

2. Obat - obatan LASA belum diberikan identifikasi khusus, tetapi ditempatkan sesuai dengan kelompok obat yang sejenis.

Data pada tabel menunjukkan bahwa determinn IKP yang terjadi, terutama adalah yang tidak menimbulkan cedera pada pasien, yaitu KTC dan KPC. Namun demikian, determinan ini tetap harus dilaporkan karena dapat digunakan sebagai data dasar perbaikan sistem pelayanan dan pencegahan IKP yang menimbulkan cedera pasien (KTD dan sentinel).

\section{Faktor Penyebab Rendahnya Laporan Insiden Keselamatan} Pasien

Hasil wawancara terstruktur dengan pejabat struktural, pimpinan unit kerja dan sub komite KPRS, sebanyak 8 orang, didapatkan informasi bahwa rendahnya laporan insiden keselamatan pasien di RSIA Malang disebabkan oleh: kurangnya pemahaman petugas untuk melaporkan IKP, kurang optimalnya pelaksanaan sistem pelaporan IKP, ketakutan untuk melaporkan dan tingginya beban kerja SDM, sehingga pelaporan IKP yang tidak menimbulkan cedera pasien cenderung tidak dilaporkan. Apabila dibandingkan dengan berbagai bentuk insiden yang ditemukan saat observasi menunjukkan bahwa faktor pemahaman tentang insiden terutama kejadian nyaris cedera dan potensi insiden merupakan contributor penting rendahnya pelaporan. 
Tabel 3. Hasil wawancara terstruktur

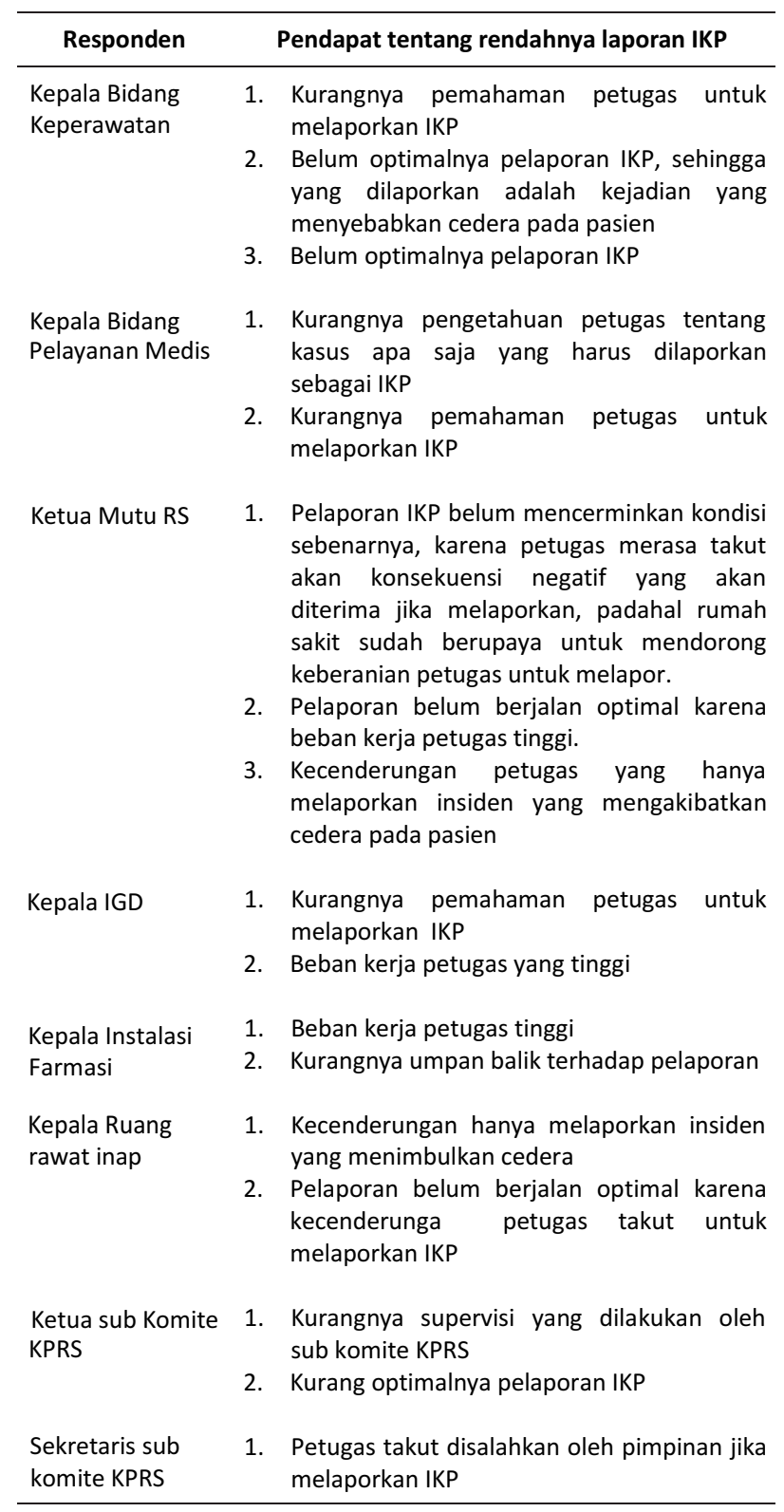

Hasil wawancara terstruktur terhadap 5 orang keluarga pasien tentang penerapan keselamatan pasien di rumah sakit, didapatkan data bahwa $100 \%$ responden menyatakan tidak tahu tentang hak pasien di rumah sakit dan $100 \%$ juga tidak paham arti tulisan yang ditempelkan oleh rumah sakit bahwa keselamatan pasien merupakan prioritas utama.

Survei dilakukan dengan metode kuesioner tertutup terhadap 20 responden. Pertanyaan yang diberikan ditinjau dari aspek pengetahuan petugas tentang insiden keselamatan pasien, persepsi petugas sistem pelaporan IKP dan persepsi petugas tentang budaya keselamatan organisasi. Berdasarkan data pada Tabel 4, didapatkan informasi bahwa $68,06 \%$ petugas mempunyai pengetahuan yang baik tentang insiden keselamatan pasien dan 31,94\% mempunyai pengetahuan kurang tentang IKP, 68,98\% petugas mempunyai persepsi baik tentang pelaporan IKP di rumah sakit dan 31,02\% mempunyai persepsi kurang. Persepsi petugas terhadap budaya keselamatan di rumah sakit adalah 78,89\% menyatakan baik dan 21,11\% menyatakan kurang. Hasil menunjukkan bahwa secara keseluruhan pengetahuan petugas tentang IKP, persepsi terhadap sistem pelaporan IKP dan budaya keselamatan pasien sudah cukup baik, namun demikian masih perlu untuk ditingkatkan.

Tabel 4. Gambaran pengetahuan dan persepsi petugas terhadap pelaporan dan budaya keselamatan pasien di RS $\mathbf{X}$ Malang

\begin{tabular}{lcc}
\hline \multicolumn{1}{c}{ Aspek pengkajian } & Baik & Kurang \\
\hline Pengetahuan petugas tentang insiden keselamatan & $68,06 \%$ & $31,94 \%$ \\
pasien & $68,98 \%$ & $31,02 \%$ \\
Persepsi petugas terhadap sistem pelaporan IKP & $78,89 \%$ & $21,89 \%$ \\
Persepsi petugas terhadap budaya keselamatan di & & \\
rumah sakit & & \\
\hline
\end{tabular}

Berdasarkan data yang diperoleh melalui wawancara terstruktur dan kuesioner diatas, maka dirumuskan faktor penyebab rendahnya laporan IKP di rumah sakit X. Hasil identifikasi faktor-faktor penyebab rendahnya laporan insiden keselamatan pasien di RS X, selanjutnya dilakukan skoring dengan menggunakan metode USG (Urgency, Seriousness, Growth) untuk menentukan permasalahan yang dianggap paling utama. Penilaian secara USG dilakukan oleh 6 orang yang terdiri dari 1 orang pejabat struktural (kepala bagian keperawatan), 4 orang pimpinan unit kerja (kepala ruang rawat inap kelas III laki-laki, kepala instalasi farmasi, kepala IGD dan kepala instalasi laboratorium) dan ketua sub komite KPRS. Skoring menggunakan skala Linkert yaitu nilai 1-5. Hasil identifikasi faktor penyebab utama rendahnya laporan IKP dan hasil USG tertera pada Tabel 5.

\section{Tabel 5. Hasil USG faktor penyebab rendahnya IKP}

\begin{tabular}{|c|c|c|c|c|}
\hline Masalah Utama & Skor U & Skor S & Skor G & Jumlah \\
\hline $\begin{array}{l}\text { Kurangnya pemahaman petugas } \\
\text { untuk melaporkan IKP }\end{array}$ & 27 & 24 & 29 & 80 \\
\hline $\begin{array}{l}\text { Kurang optimalnya superfisi sub } \\
\text { komite KPRS }\end{array}$ & 18 & 23 & 19 & 60 \\
\hline $\begin{array}{l}\text { Petugas kurang merasakan adanya } \\
\text { perlindungan yang diberikan } \\
\text { manajemen terhadap pelaporan IKP }\end{array}$ & 18 & 24 & 21 & 63 \\
\hline $\begin{array}{l}\text { Tingginya beban kerja SDM sehingga } \\
\text { tidak teliti dalam melakukan } \\
\text { identifikasi IKP }\end{array}$ & 25 & 23 & 21 & 69 \\
\hline $\begin{array}{l}\text { Kurangnya pengetahuan petugas } \\
\text { tentang determinan IKP Kurang } \\
\text { optimalnya pelaporan IKP }\end{array}$ & 15 & 24 & 18 & 57 \\
\hline $\begin{array}{l}\text { Kurang optimalnya umpan balik dari } \\
\text { sub komite KPRS terhadap pelaporan }\end{array}$ & 24 & 22 & 21 & 67 \\
\hline IKP & 12 & 24 & 16 & 52 \\
\hline $\begin{array}{l}\text { Kurangnya pengetahuan pasien dan } \\
\text { keluarga tentang hal- hal yang } \\
\text { berkaitan dengan keselamatan } \\
\text { pasien selama menjalani perawatan. }\end{array}$ & 13 & 20 & 21 & 54 \\
\hline
\end{tabular}


Berdasarkan data hasil USG didapatkan bahwa faktor penyebab utama rendahnya laporan IKP di RS X adalah kurangnya pemahaman petugas untuk melaporkan IKP, dengan jumlah skor USG yaitu 80. Faktor penyebab utama ini selanjutnya dilakukan analisis untuk menentukan akar masalah utama. Metode yang digunakan untuk menganalisis akar masalah utama adalah dengan focus group discussion (FGD), dengan melibatkan tim sub komite KPRS sebanyak 6 orang. Analisis dilakukan dengan mengidentifikasi melalui pendekatan $5 \mathrm{M}$, yaitu man, methode, machine, material dan money (Tabel 6).

Tabel 6. Identifikasi akar masalah rendahnya IKP

\begin{tabular}{|c|c|}
\hline $\begin{array}{l}\text { Aspek } \\
\text { Akar } \\
\text { Masalah }\end{array}$ & Identifikasi akar masalah \\
\hline Man & $\begin{array}{l}\text { 1. Kurangnya pengetahuan tentang determinan IKP } \\
\text { 2. Kurangnya pengetahuan petugas tentang SOP } \\
\text { pelaporan IKP } \\
\text { 3. Ketakutan petugas untuk melaporkan IKP } \\
\text { 4. Beban kerja SDM yang tinggi }\end{array}$ \\
\hline Methode & $\begin{array}{l}\text { 1. Kurangnya optimalnya sosialisasi SOP pelaporan IKP } \\
\text { 2. Kurangnya informasi terkait dukungan manajemen } \\
\text { terhadap pelaporan IKP }\end{array}$ \\
\hline Machine & $\begin{array}{l}\text { 1. Kurangnya umpan balik terhadap pelaporan IKP } \\
\text { 2. Kurangnya pelatihan terkait IKP }\end{array}$ \\
\hline Material & $\begin{array}{l}\text { 1. Kurangnya ketersediaan format pelaporan IKP } \\
\text { 2. Tidak adanya identifikasi lokasi pengiriman laporan } \\
\text { IKP } \\
\text { 3. Kurangnya pengetahuan pasien dan keluarga } \\
\text { tentang konsep keselamatan pasien selama } \\
\text { perawatan }\end{array}$ \\
\hline Money & $\begin{array}{l}\text { 1. Belum ada reward untuk tim KKPRS } \\
\text { 2. Kurangnya dukungan keuangan untuk kegiatan } \\
\text { pelatihan ekternal tentang IKP dan patient safety }\end{array}$ \\
\hline
\end{tabular}

Hasil identifikasi akar masalah selanjutnya dilakukan analisis untuk mencari akar masalah utama. Metode yang digunakan adalah FGD. FGD dilakukan bersama dengan 6 orang tim KPRS yang terdiri dari ketua, sekretaris dan anggota sebanyak 4 orang. Setiap orang akan menentukan 1 akar masalah utama. Hasil dari FGD tersebut adalah $100 \%$ menyatakan bahwa faktor man yaitu ketakutan petugas untuk melaporkan IKP merupakan akar masalah utama yang menyebabkan kurangnya pemahaman petugas untuk melaporkan IKP dan berdampak pada rendahnya laporan IKP di RSI X. Rendahnya laporan IKP memberikan dampak pada data insiden keselamatan pasien di RS $\mathrm{X}$ kurang valid, yaitu angka kejadian yang dilaporkan rendah, tetapi observasi lapangan menunjukkan bahwa angka IKP masih tinggi, terutama pada kejadian nyaris cedera dan potensial cedera.

\section{DISKUSI}

Sistem pelaporan yang baik sangat diperlukan untuk membangun budaya keselamatan pasien (1). Data pelaporan yang valid dan akurat dapat digunakan sebagai dasar untuk perbaikan sistem pelayanan dan pencegagan terhadap terjadinya IKP yang berulang(6). Data IKP di RSIA tahun 2012 dan 2013 adalah 1,03\% dan 0,44\%. Kondisi ini sangat jauh dibawah data IOM yang menyatakan angka
IKP adalah sekitar $10 \%$ dari admisi (1). Angka ini akan jauh lebih tinggi di Indonesia, karena standar pelayanan masih belum optimal (1). Hasil observasi lapangan menunjukkan bahwa dalam waktu 2 jam di IGD, 1 jam di ruang rawat inap dan 1 jam di apotik rawat jalan telah diidentifikasi IKP sebanyak 30 kejadian. Jenis insiden yang ditemukan adalah kejadian potensial cedera, kejadian nyaris cedera dan kejadian tidak cedera. Berdasarkan hasil observasi dapat disimpulkan bahwa angka insiden keselamatan pasien yang telah dilaporkan, belum menggambarkan kondisi yang sebenarnya terjadi dalam proses pelayanan rumah sakit $X$. Temuan ini sesuai dengan penelitian yang di US yang menemukan bahwa 76\%-82\%IKP di rumah sakit tidak dilaporkan (9).

Hasil wawancara terstruktur dengan pejabat struktural, pejabat fungsional, tim sub komite KPRS dan hasil kuesioner yang dilakukan terhadap petugas RS dan keluarga pasien memberikan hasil bahwa penyebab rendahnya laporan IKP adalah kurangnya pemahaman petugas untuk melaporkan IKP, kurang optimalnya superfisi sub komite KPRS, petugas kurang merasakan adanya perlindungan yang diberikan manajemen terhadap pelaporan IKP, tingginya beban kerja SDM sehingga tidak teliti dalam melakukan identifikasi IKP, kurangnya pengetahuan petugas tentang determinan IKP, kurang optimalnya umpan balik dari sub komite KPRS terhadap pelaporan IKP dan kurangnya pengetahuan pasien dan keluarga tentang hal-hal yang berkaitan dengan keselamatan pasien selama menjalani perawatan keluarga pasien. Metode skoring berdasarkan tingkat kegawatan, keseriusan dan pertumbuhan masalah dilakukan terhadap 6 faktor yang diidentifikasi menjadi penyebab rendahnya IKP di RS X. Hasil dari skoring tersebut menunjukkan bahwa kurangnya pemahaman petugas untuk melaporkan IKP merupakan faktor utama yang menyebabkan rendahnya IKP di RSX.

Rendahnya pemahaman petugas tentang IKP meliputi aspek pengetahuan petugas tentang cara melaporkan dan manfaat IKP serta konsekuensi yang akan diterima ketika melaporkan IKP. Pengetahuan cara melaporkan setidaknya dipengaruhi oleh 2 hal yaitu pengetahuan yang benar tentang IKP dan prosedur pelaporan IKP. Kurangnya pengetahuan tentang IKP mempengaruhi kemampuan petugas mengidentifikasi IKP. Sangheraa menyatakan tidak menyadari jika suatu kesalahan telah terjadi karena kurangnya kemampuan mengidentifikasi merupakan faktor penghalang laporan IKP (10). Hasil kuesioner pada petugas ditemukan yang $50 \%$ tidak tahu determinan IKP (KTD, KNC. KTC, KPC dan sentinel). Ketidaktahuan determinan IKP dapat berdampak IKP yang tidak menibulkan cedera, seperti KNC, KPC dan KTC, tidak dilaporkan. Hasil kuesioner juga menemukan bahwa $22,22 \%$ petugas tidak faham cara mengisi format pelaporan IKP. $50 \%$ responden menyatakan bahwa pimpinan unit kerja memberikan hukuman jika melaporkan kesalahan yang berisiko pada keselamatan pasien dan $37,78 \%$ responden merasa malu jika laporan yang dibuat dipresentasikan sebagai bahan kajian.

Pemahaman tentang insiden keselamatan pasien merupakan faktor yang dapat mempengaruhi pelaporan $\operatorname{IKP}(6,10)$. Arfan menyatakan bahwa komunikasi, persepsi terhadap standar prosedur operasional (SPO) dan supervisor, pengetahuan terhadap keselamatan, stres kerja dan kelelahan berpengaruh terhadap pelaporan insiden keselamatan pasien (13). Menurut teori planned 
behaviour, pengetahuan petugas tentang IKP, pengetahuan petugas tentang cara melaporkan dan manfaat IKP serta konsekuensi yang akan diterima ketika melaporkan IKP merupakan bagian dari norma subjektif yang merupakan salah satu dimensi yang mempengaruhi niat individu untuk melakukan aktivitas tertentu. Pemahaman individu terhadap sesuatu hal akan berpengaruh pada niat untuk melaporkan (14). Niat akan sangat berpengaruh pada kinerja, artinya jika masing masing petugas mempunyai niat yang kuat untuk melaporkan IKP maka kinerja pelaporan IKP juga akan semakin baik (9). Pemahaman yang kurang terhadap insiden keselamatan pasien adalah salah satu faktor yang mempengaruhi menurunnya perilaku petugas untuk melaporkan IKP $(6,10)$.

Studi ini juga menyimpulkan bahwa faktor penyebab lain dari kurangnya pemahaman petugas untuk melaporkan IKP adalah kurangnya pengetahuan petugas tentang IKP. Faktor ini menarik untuk dicermati karena terdapat inkonsistensi pemahaman dari hasil kuesioner. Data kuesioner mendapatkan $72,22 \%$ responden menyatakan paham terhadap IKP dan cara pelaporannya, tetapi hanya $50 \%$ yang mengetahui determinan IKP. Kondisi ini menjadi lebih nyata ketika diberikan pertanyaan yang sifatnya pengetahuan tentang ruang lingkup keselamatan pasien, $94,44 \%$ responden mempunyai jawaban yang salah, seharusnya pelaporan IKP adalah salah satu dari 7 langkah keselamatan pasien. Kondisi ini perlu untuk dicermati, karena pengetahuan sangat berpengaruh pada kemampuan petugas untuk melakukan identifikasi IKP (11). Data kuesioner menunjukkan $83,33 \%$ responden pernah mendapatkan pelatihan IKP minimal 1 tahu sekali. Hasil wawancara terstruktur dengan ketua Sub Komite KPRS menyatakan bahwa evaluasi pelatihan yang dilakukan adalah dalam bentuk pretest dan post test, namun belum ada evaluasi yang bersifat jangka menengah dan panjang terkait pengaplikasian hasil pelatihan. Data studi ini dapat menjadi pertimbangan untuk merumuskan model sistem monitoring dan evaluasi paska pelatihan IKP.

Pengkajian akar masalah yang menjadi faktor penyebab kurangnya pemahaman petugas tentang IKP dilakukan dengan focus group discussion (FGD) dengan melibatkan 6 orang tim sub komite KPRS, yang terdiri dari ketua, sekretaris dan anggota. Hasil FGD menyimpulan bahwa petugas merasa takut disalahkan oleh pimpinan jika melaporkan IKP adalah akar masalah yang menyebabkan kurangnya pemahaman petugas tentang IKP yang berdampak pada rendahnya laporan IKP di RS X. Data ini sesuai dengan hasil kuesioner yang menunjukkan bahwa $50 \%$ responden menyatakan bahwa atasan memberikan sangsi jika melaporkan insiden keselamatan pasien. Temuan ini juga sesuai dengan penelitian Chiang dan Pepper bahwa salah satu kendala pelaporan IKP adalah faktor takut. Faktor takut ini meliputi takut disalahkan, takut efek samping dari melapor, takut sikap pasien yang negatif, takut teguran, takut dianggap tidak mengetahui jika terjadi IKP dan takut dicap tidak kompeten (15).

Ketakutan adalah tanggapan emosi terhadap ancaman. Ketakutan berhubungan dengan persepsi individu terhadap risiko yang akan diterima ketika melakukan aktivitas tertentu (8). Ketakutan petugas petugas untuk melaporkan IKP didasari oleh konsekuensi negatif yang akan diterima dari pimpinannya. Uribe, Koohestani, Ginsburg menyatakan bahwa ketakutan untuk melaporkan karena konsekuensi yang harus diterima merupakan faktor penghalang dalam pelaporan IKP $(7,11,16)$. Kesalahan yang tidak dilaporkan akan berdampak bagi rumah sakit dengan kehilangan kesempatan untuk belajar dari kesalahan untuk selanjutnya memperbaiki dan membangun sistem yang lebih aman (17). Kondisi ini akan menjadi faktor penghambat bagi rumah sakit untuk membangun budaya keselamatan pasien.

Faktor penyebab lain yang perlu mendapatkan perhatian adalah kurang optimalnya umpan balik yang diberikan oleh tim KPRS terhadap pelaporan IKP. Hasil kuesioner 44,44\% menyatakan bahwa tim KPRS tidak merespon laporan IKP dan $11,11 \%$ menyatakan tidak tahu. Jika dua komponen ini digabungkan makan 55,55\% responden menyatakan kurang optimalnya respon tim KPRS terhadap laporan IKP. Pendapat responden terkait umpan balik terhadap pelaporan, 38,89\% menyatakan tidak ada umpan balik dan 22,22\% menyatakan tidak tahu. Jika 2 aspek ini dijumlahkan maka dapat diambil kesimpulan 61,11\% responden menyatakan bahwa tim KPRS kurang optimal dalam memberikan umpan balik terhadap pelaporan IKP. Kondisi ini akan menjadi faktor penghambat dalam mewujudkan sistem pelaporan IKP yang baik dan sukses. Sorra et al menyatakan bahwa budaya keselamatan pasien harus didukung oleh komunikasi yang terbuka, adanya feedback dan komunikasi jika ada kesalahan, tidak ada hukuman dan bahkan pemberian hadiah bagi mereka yang melaporkan, budaya pihak manajemen dan pembelajaran organisasi yang terus menerus (18).

Upaya untuk melakukan perbaikan data pelaporan IKP di RS X dapat dilakukan dengan memberikan solusi terhadap faktor-faktor yang mempengaruhi pemahaman petugas untuk melaporkan IKP. Pembuatan plan of action dapat membantu program optimalisasi pelaporan IKP di RSIA. Prioritas solusi disesuaikan dengan identifikasi akar masalah utama yaitu rasa takut untuk melaporkan, karena aspek ketakutannya adalah pada pimpinan unit kerja, maka sosialisasi merupakan langkah yang strategis. Kepemimpinan sangat berpengaruh pada kinerja karyawan. Peran pimpinan dalam memberikan rasa aman, dengan tidak menyalahkan sangat membantu terwujudnya sistem pelaporan yang sukses. Hwang menyatakan faktor organisasi merupakan salah satu faktor yang berpengaruh pada pelaporan IKP. Fungsi manajemen dalam mengelola keselamatan pasien berpengaruh pada pelaporan IKP. Lemahnya kepemimpinan organisasi terhadap keselamatan pasien merupakan faktor penghalang pelaporan IKP (6).

Hasil studi ini menyimpulkan bahwa rendahnya angka insiden keselamatan pasien di RS X tidak menggambarkan kondisi yang sebenarnya terjadi. Masalah utama yang menyebabkan adalah kurangnya pemahaman petugas tentang IKP yang disebabkan oleh ketakutan petugas terhadap konsekuensi negatif yang diterima ketika melaporkan IKP. Kondisi ini berdampak pada rendahnya pelaporan IKP. Pelaporan IKP yang tidak adekuat akan membuat rumah sakit kehilangan kesempatan untuk melakukan identifikasi faktor risiko dan perbaikan sistem pelayanan yang menuju pada keselamatan pasien.

Salah satu tujuan budaya keselamatan pasien adalah membangun sistem yang memungkinkan mencegah terjadinya kesalahan yang berulang. Peran manajemen rumah sakit untuk membuat sistem pelayanan yang mempertimbangkan evidence basedyang diperoleh dari 
data pelaporan dan umpan balik serta rekomendasi sub komite KPRS perlu untuk dilakukan. Kondisi ini akan membuat seluruh staf rumah sakit merasakan adanya dukungan manajemen dalam pelaksanaan budaya

\section{DAFTAR PUSTAKA}

1. Departemen Kesehatan Republik Indonesia. Panduan Nasional Keselamatan Pasien Rumah Sakit. Jakarta: Departemen Kesehatan RI; 2006.

2. Forster AJ, Dervin G, Martin, Cjr., and Papp S. Improving Patient Safety through the Systematic Evaluation of Patient Outcomes. Canadian Journal of Surgery. 2012; 55: 418-425.

3. Mulyana DS. Analisis Penyebab Insiden Keselamatan Pasien oleh Perawat di Unit Rawat Inap Rumah SakitX Jakarta. [Tesis]. Universitas Indonesia, Jakarta. 2013.

4. Rumah Sakit X. Laporan Tahunan Rumah Sakit $X$ Malang tahun 2012. Malang: Rumah Sakit X; 2012.

5. Rumah Sakit X. Laporan Tahunan Rumah Sakit $X$ Malang tahun 2013. Malang: Rumah Sakit X; 2013.

6. Hwang $\mathrm{JI}$, Lee $\mathrm{SI}$, and Park HA. Barriers to the Operation of Patient Safety Incident Reporting System in Korean General Hospital. Healthcare Informatics Research. 2012; 18(4): 279-286.

7. Koohestani HR and Baghcheghi N. Barrier to the Reporting of Medication Administration Errors among Nursing Students. Australian Journal of Advanced Nursing. 2009; 27(1): 66-74.

8. The Health Foundation. Evidence Scan: Does Improving Safety Culture Affect Patient Outcomes? ( O n I i n e )

2011 . http://www.health.org.uk/sites/default/files/Doesl mprovingSafetyCultureAffectPatientOutcomes.pdf.

9. Kingston MJ, Evans SM, Smith BJ, and Berry JG. Attitudes of Doctors and Nurses towards Incident Reporting: A Qualitative Analysis. MJA. 2004; 181(1): 36-39.

10. Sanghera IS, Franklin BD, and Dhillon S. The Attitudes and Beliefs of Healthcare Professionals on the Causes keselamatan pasien. Peran manajemen rumah sakit untuk memberikan solusi terhadap akar masalah utama perlu dilakukan. Pelaporan IKP yang baik merupakan salah satu syarat terwujudnya budaya keselamatan pasien.

and Reporting of Medication Errors in a UK Intensive Care Unit. Anaesthesia. 2007; 62(1): 53-61.

11. Uribe CL and Sharon BS. Perceived Barrier to Medical Error Reporting: An Exploratory Investigation. Journal of Public Health Management and Practice 2002; 47(4): 263-279.

12. Karadeniz G and Cakmakci A. Nurses' Perceptions of Medication Errors. International Journal of Clinical Pharmachology Research. 2002; 22(3-4): 111-116.

13. Arfan AN, Pasinringi SA, dan Sidin Al. Gambaran Determinan Insiden Keselamatan Pasien pada Petugas Kesehatan di Rumah Sakit Universitas Hasanudin. [Tesis]. Universitas Hasanuddin, Makasar. 2013.

14. Ajzen I. Attitudes, Personality and Behaviour. 2nd edition. London: McGraw-Hill Education; 2005.

15. Chiang HY and Pepper GA. Barriers to Nurses' Reporting of Medication Administration Errors in Taiwan. Journal of Nursing Scholarship. 2006; 38(4): 392-399.

16. Ginsburg L, Tregunno D, Fleming $M$, Gilin D, and Norton P. (Online) 2008. Patient Safety Culture: Improving Measurement and Establishing Links to Patient Safety Activity. htt $p: / / w w w . p a t i e n t s a f e t y i n s t i t u t e$. ca/en/search/pages/results.aspx?k=Ginsburg,\%20L., \%20Tregunno,\%20D.,\%20Fleming,\%20M.,\%20Gilin,\% 20D.\%20\&\%20Norton

17. World Health Organization. Word Alliance for Patient Safety : WHO Draf Guidelines for Adverse Events Reporting and Learning System. Genewa: WHO; 2005.

18. Sorra JS and Dyer N. Multilevel Paycometric Properties of the AHRQ Hospital Survey on Patient Safety Culture. BioMed Central Health Services Research. 2010; 10(199): 1-13. 
Bambaran pengetahuan petugas tentang IKP, persepsi petugas terhadap pelaporan IKP dan persepsi petugas terhadap budaya keselamatan pasien di RS X Malang

\begin{tabular}{|c|c|c|c|}
\hline Pertanyaan Kuesioner & Ya & Tidak & Tidak Tahu \\
\hline \multicolumn{4}{|l|}{ Aspek pengetahuan petugas tentang IKP } \\
\hline Saya sangat paham dengan apa yang dimaksud IKP dan cara melaporkannya & $72,22 \%$ & $11,11 \%$ & $16,67 \%$ \\
\hline \multicolumn{4}{|l|}{ Saya tahu SPO pelaporan IKP yang diberlakukan di RSI Aisyiyah Malang } \\
\hline $\begin{array}{l}\text { Saya mengetahui determinan kejadian yang berhubungan dengan insiden keselamatan } \\
\text { pasien }\end{array}$ & $88,89 \%$ & $11,11 \%$ & $0,00 \%$ \\
\hline Saya tahu format yang digunakan untuk pelaporan IKP & $50,00 \%$ & $38,89 \%$ & $11,11 \%$ \\
\hline \multicolumn{4}{|l|}{ Tidak semua kejadian IKP harus dilaporkan pada KKPRS } \\
\hline Hanya kejadian yang menimbulkan dampak nyata pada pasien yang harus dilaporkan pada & $88,89 \%$ & $11,11 \%$ & $0,00 \%$ \\
\hline KKPRS & $11,11 \%$ & $77,78 \%$ & $11,11 \%$ \\
\hline Saya tidak tahu kegunaan pelaporan IKP & $16,67 \%$ & $83,33 \%$ & $0,00 \%$ \\
\hline \multicolumn{4}{|l|}{ Saya tahu kegunaan laporan IKP } \\
\hline Pelaporan IKP adalah salah satu dari lima langkah untuk mewujudkan budaya & $5,56 \%$ & $94,44 \%$ & $0,00 \%$ \\
\hline keselamatan pasien & $94,44 \%$ & $5,56 \%$ & $0,00 \%$ \\
\hline $\begin{array}{l}\text { Terdapat } 4 \text { sasaran keselamatan pasien yang harus diperhatikan dalam pelayanan rumah } \\
\text { sakit }\end{array}$ & $94,44 \%$ & $5,56 \%$ & $0,00 \%$ \\
\hline \multicolumn{4}{|l|}{ Faktor penyebab utama IKP adalah SDM, bukan pada sistem pelayanan } \\
\hline \multirow[t]{3}{*}{ Saya belum paham cara pengisian format pelaporan IKP } & $61,11 \%$ & $16,67 \%$ & $22,22 \%$ \\
\hline & $11,11 \%$ & $83,33 \%$ & $5,56 \%$ \\
\hline & $16,67 \%$ & $77,78 \%$ & $5,56 \%$ \\
\hline \multicolumn{4}{|l|}{ Aspek persepsi petugas terhadap sistem pelaporan IKP } \\
\hline $\begin{array}{l}\text { Menurut pendapat Saya sistem pelaporan IKP di rumah sakit ini sudah berjalan dengan } \\
\text { baik }\end{array}$ & $33,33 \%$ & $50,00 \%$ & $16,67 \%$ \\
\hline $\begin{array}{l}\text { Atasan akan memberikan sangsi jika Saya melakukan tindakan yang beresiko pada } \\
\text { keselamatan pasien }\end{array}$ & $50,00 \%$ & $38,89 \%$ & $11,11 \%$ \\
\hline $\begin{array}{l}\text { Saya takut untuk melaporkan kejadian keselamatan pasien yang terjadi akibat kelalaian } \\
\text { Saya sendiri }\end{array}$ & $11,11 \%$ & $88,89 \%$ & $0,00 \%$ \\
\hline $\begin{array}{l}\text { Saya tidak akan melaporkan IKP yang diakibatkan oleh kolega saya, untuk menghindari } \\
\text { konflik dalam tim }\end{array}$ & $5,56 \%$ & $88,89 \%$ & $5,56 \%$ \\
\hline Saya takut didskriminasikan oleh teman satu grup jika melaporkan kejadian IKP & $11,11 \%$ & $83,33 \%$ & $5,56 \%$ \\
\hline \multicolumn{4}{|l|}{ Menurut Saya, pelaporan IKP ibarat tugas ekstra yang menambah beban kerja } \\
\hline $\begin{array}{l}\text { Saya malu jika laporan Saya dibahas dalam forum dan diminta untuk menjelaskan } \\
\text { kronologisnya. }\end{array}$ & $27,78 \%$ & $72,22 \%$ & $0,00 \%$ \\
\hline Saya takut kehilangan pekerjaan akibat laporan IKP yang Saya lakukan & $22,22 \%$ & $72,22 \%$ & $5,56 \%$ \\
\hline $\begin{array}{l}\text { kesalahan yang berdampak IKP dan mau untuk melaporkan } \\
\text { Laporan IKP yang banyak beresiko buruk terhadap citra rumah sakit }\end{array}$ & $22,22 \%$ & $77,78 \%$ & $0,00 \%$ \\
\hline Saya khawatir dianggap tidak profesional/kompeten ketika melakukan pelaporan IKP & $44,44 \%$ & $5,56 \%$ & $50,00 \%$ \\
\hline \multirow[t]{3}{*}{ Saya pernah melakukan tindakan pelayanan pasien yang berdampak IKP } & $33,33 \%$ & $66,67 \%$ & $0,00 \%$ \\
\hline & $11,11 \%$ & $83,33 \%$ & $5,56 \%$ \\
\hline & $77,78 \%$ & $22,22 \%$ & $0,00 \%$ \\
\hline \multicolumn{4}{|l|}{ Aspek persepsi budaya organisasi } \\
\hline $\begin{array}{l}\text { Keselamatan pasien adalah menjadi prioritas dalam pelayanan } \\
\text { kesehatan }\end{array}$ & $100,00 \%$ & $0,00 \%$ & $0,00 \%$ \\
\hline $\begin{array}{l}\text { Pelayanan rumah sakit tidak dapat terbebas sepenuhnya dari } \\
\text { terjadinya Insiden Keselamatan Pasien (IKP) }\end{array}$ & $88,89 \%$ & $11,11 \%$ & $0,00 \%$ \\
\hline $\begin{array}{l}\text { Pelaporan IKP harus dikelola dan dilaporkan untuk menjamin } \\
\text { mutu pelayanan yang berorientasi pada keselamatan pasien }\end{array}$ & $100,00 \%$ & $0,00 \%$ & $0,00 \%$ \\
\hline $\begin{array}{l}\text { Rumah sakit ini mempunyai tim yang bertanggungjawab terhadap } \\
\text { pengelolaan IKP dan telah ada surat keputusan direktur }\end{array}$ & $77,78 \%$ & $0,00 \%$ & $22,22 \%$ \\
\hline Saya tahu tempat untuk meletakkan laporan IKP & $72,22 \%$ & $22,22 \%$ & $5,56 \%$ \\
\hline KKPRS akan langsung merespon setiap laporan yang dikirimkan & $44,44 \%$ & $44,44 \%$ & $11,11 \%$ \\
\hline Selalu ada umpan balik dan respon terhadap laporan IKP & $38,89 \%$ & $38,89 \%$ & $22,22 \%$ \\
\hline $\begin{array}{l}\text { Saya selalu mendapatkan pelatihan IKP paling sedikit } 1 \text { tahun } \\
\text { sekali }\end{array}$ & $83,33 \%$ & $16,67 \%$ & $0,00 \%$ \\
\hline $\begin{array}{l}\text { Dalam tim kerja Saya, selalu saling mengingatkan dan mendukung } \\
\text { untuk melaporkan setiap IKP }\end{array}$ & $94,44 \%$ & $5,56 \%$ & $0,00 \%$ \\
\hline Format laporan IKP selalu tersedia di ruangan Saya. & $88,89 \%$ & $11,11 \%$ & $0,00 \%$ \\
\hline
\end{tabular}

